\title{
Moniäänisesti aikuiskasvatuksen vaikuttajista
}

Kari Kantasalmi ja Mauri Nest (toim.) (2014). Valistajia, sivistäjiä, poliitikkoja ja asiantuntijoita. Näkökulmia aikuiskasvatuksen kentän vaikuttajiin. Tampere: Tampere University Press. 395 s. ISBN: 978-951-44-9612-7

PYRKIMYS HAHMOTTAA OMaa menneisyyttä on ihmiselämän erottamaton osa. Tämä pätee yhtä hyvin yksilöihin kuin erilaisiin yhteisöihin ja instituutioihin, kuten puolueisiin, virastoihin tai tieteenaloihin. Nyt tarkasteltavana olevan teoksen tarkoitus on rikastuttaa aikuiskasvatustieteen parissa työskentelevien itseymmärrystä.

Teos koostuu viidestätoista artikkelista, joiden kirjoittajat edustavat eri tieteenaloja ja toimijaryhmiä. Suurin osa kirjoittajista tulee kasvatustieteen tai aikuiskasvatustieteen ulkopuolelta, mistä johtuen tarjolla on runsaasti lukijan iloisesti yllättäviä tulkintoja. Erityisosaamisen kääntöpuolena on tarkastelujen saarekemaisuus. Välillä tahtoo aikuiskasvatuskin jäädä taka-alalle. Kyseessä ei ole yhtenäisen juonen muodostava kokonaisesitys, vaan lukijan täytyy itse kutoa se punainen lanka, jolla tekstit voi toisiinsa yhdistää.

Ensimmäistä ja viimeistä artikkelia lukuun ottamatta tarkastelu kiinnittyy valittuun avainhenkilöön. Teos on jaettu kolmeen, jonkinmoisen ajallisen jatkumon muodostavaan pääjaksoon. Ensimmäisenä on vuorossa valistuksen varhaisvaiheita esittelevä osio. Toisen pääjakson teemana on kansansivistystyön aatteellinen ja organisatorinen eriytyminen. Kolmannessa jaksossa tarkastellaan kehityslinjoja, joille oman aikamme aikuiskasvatus rakentuu.

\section{VALISTUKSEN VARHAISET VAIHEET}

Ensimmäisen jakson avaa 1700-luvun lopulla perustettua Suomen Talousseuraa tarkasteleva Jani Marjasen artikkeli. Seuran lähtökohdat ja toiminnan keskeiset piirteet esitellään pääpiirteis- sään. Myös Ahlmanin kouluista kerrotaan, vaikka seuran kannalta kyse oli epäonnistuneesta yrityksestä muuttaa alkeisopetuksen käytänteitä. Vähemmälle huomiolle kuitenkin jää, että seura tarjosi jäsenilleen uudenlaisen julkisen tilan, jossa sääty-yhteiskunnan tapakoodi ei enää pätenytkään.

Siinä missä aiemmin ihmisen arvo oli määrittynyt hänen virka-asemansa tai syntyperänsä mukaan, korostettiin nyt hänen todellisia ansioitaan. Kunnioituksen arvoinen oli mies, joka ymmärsi yhteisen hyvän edistämisen olevan itsekästä oman edun tavoittelua tärkeämpää. Tällainen talouspatriotismi oli varhaisen kansansivistystyön keskeisin liikkeellepaneva voima, minkä olisi voinut tuoda nyt tehtyä painokkaammin esiin. 


\section{SIVISTYSPOLITIIKKA SYNTYY}

Myös Anders Chydenius (1729$1803)$ piti tärkeänä edistää taloudellista kehitystä. Nykypäivänä hänet muistetaan lähinnä talousliberalismin varhaisena kannattajana. Juha Manninen esittelee toisenlaisen Chydeniuksen, joka kyllä hyväksyi talouden säätelyn, kunhan vain pysytään järkevissä rajoissa. Jotta säätely ei haittaisi talouskehitystä, ihmisillä oli oltava oikeus osallistua yhteiskunnallista päätöksentekoa koskevaan keskusteluun. Viisas politiikka perustui asioiden yhteiselle pohdinnalle, mikä puolestaan edellytti paitsi mielipiteen ilmaisun vapautta myös kansan valistamista. Talouspolitiikka vaati siten rinnalleen sivistyspolitiikkaa.

Chydeniuksen varmuus kantojensa oikeellisuudesta saattoi johtua tuolloin vallalla olleesta uskomuksesta, jonka mukaan Suomi oli luonnonvaroiltaan poikkeuksellisen rikas maa. Jos asia oli näin, silloin köyhyyden syynä täytyi olla taloudelliselle toimeliaisuudelle asetetut esteet tai ihmisten tietämättömyys tai molemmat. Jälkimmäistä puutetta Talousseura ryhtyi sittemmin tarmokkaasti poistamaan.

\section{Sivistyskäsitys muotoutuu}

J.V. Snellmania (1806-1881) käsittelevä artikkeli tarjoaa sekin tuoreen näkökulman sinällään kaluttuun aiheeseen. Mikko Lahtinen kaivaa esiin arkipäivän ongel- miin puuttuvan yhteiskunnallisen vaikuttajan, jonka ajattelussa teoreettinen katsantokanta nivoutuu erottamattomasti päiväkohtaisiin kysymyksiin. Myös sivistyksen käsite saa artikkelissa uudenlaisen merkityksen.

Kyse näyttäisi olevan taloudellisen toimeliaisuuden aikaansaamasta hyvinvoinnin noususta, joka puolestaan mahdollisti kulttuurisen kehittymisen. Jotta elinkeinot edistyisivät, talouden säätelyä oli purettava ja ihmisille oli tarjottava tarpeellisia tietoja ja taitoja. Näin elinkeinovapaus edellytti rinnalleen kattavan koulutusjärjestelmän. Lisäksi oli parannettava suomen kielen asemaa, sillä olihan tietämättömyys suurinta juuri suomenkielisten parissa. Talouselämän tärkeyttä korostaessaan Snellman on samalla tavoin hegeliläinen kuin aikalaisensa Ludvig Feuerbach tai Karl Marx - itsenäinen ja ajassaan kiinni oleva ajattelija siis.

\section{Ei vain sivistyneistön projekti}

Edellisten tapaan tuoreita näkökulmia tarjoaa myös Kansanvalistusseuraa ja sen pitkäaikaista sihteeriä Axel August Granfeltia (1846-1919) käsittelevä Eero Ojasen artikkeli. Heti alussa kirjoittaja kiistää näkemyksen, jonka mukaan varhainen kansanvalistustyö olisi ollut sivistyneistön projekti, jonka tarkoituksena oli kaataa kansan päähän valmista tietoa ja suomalaisuusaatetta.
Olen itse kummastellut, mihin asiaperusteisiin tämä usein toistettu käsitys nojautuu. Ojasen mukaan syynä saattaa olla se, että asiaa tutkittaessa painopiste on ollut poliittisessa historiassa eikä niinkään sivistystoiminnan omissa lähtökohdissa. Jos ajalle ominaisen poliittisen retoriikan sijaan tarkastellaan itse toimintaa, Kansanvalistusseura näyttäytyy lähinnä kustannusliikkeenä, joka oli ottanut tehtäväkseen suomalaisen ja ennen kaikkea suomenkielisen kulttuurin edistämisen. Tämä selittää myös sen, miksi seura osallistui vahvasti myös kunnallisen kirjastolaitoksen rakentamiseen. Sihteerinsä A.A. Granfeltin aloitteesta seura otti ohjelmaansa myös laulujuhlat. Näin sivistystä ja sivistynyttä elämäntapaa edistettiin myös musiikin keinoin.

Artikkelinsa lopussa Ojanen viittaa yhteen vähän tunnettuun kansansivistystyön muotoon, nimittäin tietoisin toimenpitein toteutettuun perhe-elämän uudistamiseen. Vuosisatojen ajan pappilat olivat tarjonneet rahvaalle esikuvan kristillisestä perhe-elämästä. Kansallisuusaatteen myötä tämä tehtävä siirtyi osin sivistyneistöperheille. Näiden piirissä kehiteltiin uudenlaisia käytänteitä ja jopa uusia traditioita, jotka sitten aikaa myöten levisivät rahvaan pariin. Esimerkkinä Ojanen mainitsee joulun vieton. Harva tulee ajatelleeksi, että siirtymä Jukolan veljesten oluthuuruisesta juhlin- 
nasta hillittyyn joulupukin odotukseen toteutui vasta 1800-luvun lopulla.

\section{VAPAAN SIVISTYSTYÖN ERIYTYMINEN}

Kirjan toisen jakson avaa Lahden kansanopiston johtajana toimineen Edla Kojosen (18791955) elämäntarina. Keskittyessään yhteen toimijaan ja hänen elämänvaiheisiinsa Anna Halme onnistuu tarjoamaan monipuolisen kuvan niistä vaatimuksista ja vaikeuksista, joita 1900-luvun alkupuoliskolla kansansivistystyötä tekevä nainen joutui kohtaamaan. Kerronta noudattaa uskollisesti Kojosen elämäntaivalta avaten samalla kurkistusikkunan 1900-luvun alkupuolen yhteiskunnalliseen todellisuuteen. Samalla lukija saa monipuolisen kuvan kansanopiston työntäyteisestä arjesta.

\section{Tasa-arvon edistäjä}

Kojosen elämä kiinnittyi selväpiirteisesti kansanopistotyöhön. Hedvig Gebhardin (1867-1961) kytkökset kansansivistystyöhön ovat jo vaikeammin hahmotettavia. Helpointa olisi todeta hänen olleen Hannes Gebhardin vaimo ja siten vahvasti mukana osuustoimintaa edistävän Pellervo-seuran toiminnassa. Pellervolaisuuden ohella hän oli kuitenkin myös tinkimätön sukupuolten tasa-arvon edistäjä ja naisasianainen.

Artikkelissaan Riitta Mäkinen huomioikin ylioppilasnei- tojen keskustelukerhon mutta sivuuttaa Gebhardin panoksen Kotiliesi-lehden toimituskunnan jäsenenä. Tätäkin olisi ollut hyvä pohdiskella. Naisen taloudellinen itsenäisyys oli keskeinen osa sukupuolten välistä tasa-arvoa. Niinpä Gebhard pohti vakavissaan, olisiko perustettava erityinen naisten osuustoimintaliike. Tämä jäi tekemättä, mitä hän syystäkin myöhemmin katui. Jälkikäteen katsoen vaikuttaakin siltä, että Hedvig Gebhard ymmärsi osuustoiminnan päätehtävän miestään paremmin.

\section{Kohteena maaseudun väestö}

Kansansivistystyön vaiheita tarkasteltaessa ei voi jättää huomiotta nuorisoseuraa ja Santeri Alkiota (1862-1930). Hän kuuluu niihin itseoppineisiin, jotka toiveistaan huolimatta eivät saaneet aikanaan opintielle lähteä. Vaikka nuorisoseuraliikkeen nousu autonomian ajan lopulla onkin Alkion suurimpia saavutuksia, osallistui hän kansanvalistustyöhön myös sanomalehtimiehenä, puhujana ja kirjailijana. Nämä kaikki olivat osa samaa valistustyötä, jonka päämääränä oli kehittää suomalaisten siveellistä luonnetta, älyä ja käytännöllisyyttä. Seppo Niemelä rakentaa artikkelissaan hienon kokonaiskuvan alkiolaisesta sivistysohjelmasta.

Kun otetaan huomioon kunnallisen itsehallinnon synty 1860-luvulla, osuustoiminnan vi- riäminen vuosituhannen vaihteen tienoilla ja yleisen äänioikeuden toteutuminen valtiollisissa vaaleissa vuonna 1906, nuorisoseuratyön merkitystä maaseutuväen yhteiskunnallisena herättäjänä on vaikea yliarvioida. Tämän tietäen tuntuu kummalliselta, miksi Niemelä haluaa paikallistaa nuorisoseuraliikkeen juuret J. G. Herderiin (1744-1803). Pidän selviönä, että saksalaista filosofiaa enemmän nuorisoseuratoiminnan käynnistymiseen vaikuttivat pitäjille asetettu velvollisuus huolehtia köyhistään sekä yritykset torjua nälänhätää perustamalla viljamakasiineja ja opettamalla kansa viljelemään perunaa.

\section{Vallankumouksellinen työväenliike}

Nuorisoseuraliikkeen ja alussa myös osuustoiminnan kohdejoukkona olivat maaseudulla asuvat vähävaraiset. Mutta myös työväestön yhteiskunnallisen aseman kohottamisessa nousi omaehtoinen opiskelu tärkeään asemaan. Maria Lähteenmäki tarkastelee artikkelissaan professori Väinö Voionmaan (1869-1947) toimintaa sivistystyön käynnistäjänä ja ylläpitäjänä sosialidemokraattisessa työväenliikkeessä.

Vaikka Voionmaa oli ensi sijassa yliopistomies ja kansanedustaja, hänen työtään näillä aloilla on vaikea hahmottaa tuntematta hänen sivistyspoliittisia näkökantojaan. Yhteiskunnan ristiriidat 
sikisivät tietämättömyydestä, sillä ilman pätevää tietoa ihmisten oli vaikea hahmottaa, miten he voisivat olojaan kohentaa. Voionmaa kuitenkin katsoi, ettei sivistys voinut levitä kansan keskuuteen ellei ensin sen taloudellista asemaa kohenneta. Näin esimerkiksi palkkatasoa koskeva säätely mahdollisti kansan sivistystason nousun, mikä puolestaan tasoitti ristiriitoja luoden samalla pohjan rauhanomaisin keinoin tapahtuvalle yhteiskunnan kehittämiselle.

Kokonaan toisenlaista kantaa edusti vallankumouksellinen työväenliike, jota artikkelikokoelmassa edustaa vuonna 1994 konkurssiin ajautunut Sirola-opisto. Joni Krekola on sisällyttänyt artikkeliinsa Yrjö Sirolan (1876-1936) elämänvaiheiden ja katsantokantojen esittelyn, mikä on sikäli perusteltua, että vuonna 1946 toimintansa aloittanut kansankorkeakoulu kantoi hänen nimeään. Itse opiston toimintaan Sirolalla ei ollut osaa eikä arpaa, sillä hän oli menehtynyt sairauteen Neuvostoliitossa jo 1930-luvulla.

Sirola-opistoa voi hyvin pitää suomalaisen aikuiskasvatuksen kummajaisena, jonka erityislaatu olisi voitu artikkelissa tuoda selkeämmin esiin. Neuvostoliitossa muotoiltu marxilainen ortodoksia ei nähnyt vaihtoehtoa vallankumoukselle, minkä tähden sosialidemokraattien reformipolitiikka tuomittiin revisionismina. Valistuksen tai sivistystyön sijasta puhuttiin propaganda- ja agitaatiotyöstä. Olisikin ollut virkistävää lukea, miltä Sirola-opiston toiminta näyttäytyisi vapaan sivistystyön diskurssin valossa.

Mauri Nest tarkastelee artikkelissaan käytännön opistotyötä 1900-luvun alkupuolella. Kiinnekohtana on kaksi keskeistä toimijaa, nimittäin Tampereen ja Turun työväenopistoja johtanut Severi Nuormaa (1865-1924) ja Helsingin työväenopistossa ja Yhteiskunnallisessa korkeakoulussa opettanut Zachris Castrén (1868-1938). Heitä molempia yhdisti nuorsuomalainen tausta ja halu säilyttää työväenopiston riippumattomuus niin esivaltaan kuin puolueisiinkin nähden.

Työväenopiston tarkoitus ei ollut vastata valtion tai työväenpuolueen vaan työväestön sivistystarpeisiin. Vastaavasti toiminnan päämääränä ei ollut tietojen jakaminen vaan ihmisten "herättäminen tietoon ja henkiseen viljelyyn", kuten Nuormaa asian ilmaisi. Kahden päähenkilönsä avulla Nest onnistuu tarjoamaan elävän ajankuvan työväestön parissa tehdystä sivistystyöstä 1900-luvun ensimmäisten vuosikymmenten aikana.

\section{Ammattikasvatuksen vaiheita}

Ammattikasvatus on erottamaton osa aikuiskasvatuksen kenttää. Tätä osa-aluetta Anja Heikkinen valottaa kolmen avainhenkilön avulla. Nämä ovat maaherra, se- naattori ja finanssitoimikunnan päällikkö Lars Gabriel von Haartman (1789-1859), professori ja osuustoimintamies Hannes Gebhard (1864-1933) sekä ammattikoulun opettaja, ammattikoulujen tarkastaja ja teollisuuskoulun lehtori Jalmari Kekkonen (18781948). Vaikka nämä kaikki liittyvät tavalla tai toisella ammattikasvatuksen vaiheisiin, he edustivat perin erilaisia katsantokantoja.

Von Haartmanin tarkoituksena näyttää olleen pitää oppipojat ja kisällit poissa pahanteosta ja saattaa heidät sen sijaan sunnuntaikoulun huomaan. Gebhard puolestaan halusi vahvistaa köyhän kansan ja siten myös ammatinharjoittajien elämänhallintaa osuustoiminnan ja pienviljelijöiden neuvonnan avulla. Kekkosen toiminnassa taas korostui koulumainen ammattiopetus, jonka päämääränä oli yhtäältä ammatillinen itsekasvatus ja toisaalta työntekijän arvon tunnustava työnjohtajakoulutus. Kiintoisa artikkeli, jonka erikoisuutena on henkilökohtaisten sukulaisuus- ja tuttavuusverkostojen esittely. Kovin on pienissä piireissä asioita kehitelty ja päätöksiä tehty.

\section{Aikuiskasvatuksen ammatillistuminen}

Jo Nuormaan artikkelissa keskushenkilönä oli Zacharis Castrén. Hivenen yllättäen Castrén on esillä myös Kari Kantasalmen tekstissä, jossa toisena päähenkilönä on 
Urpo Harva (1910-1994). Varsinainen pääasia näyttäisi kuitenkin olevan aikuiskasvattajan ammatillistuminen, tai oikeammin professionalismin mahdollisuudet ja rajat. Mukaan on mahdutettu myös sosiologian teoriaa ja semantiikkaa.

Kantasalmen artikkeli poikkeaa ratkaisevasti niin kieleltään kuin rakenteeltaan kokoelman muista teksteistä. Jos on tarkoitus vertailla kahta keskeistä hahmoa, niin sitten vertailtakoon. Jos taas on tarkoitus esitellä aikuiskasvatusalan toimijoiden ammatillistumista, niin sitten tulisi keskittyä siihen. Nyt kohtalaisen pieneen tilaan on mahdutettu vähintään neljän artikkelin ainekset. Itse jäin pohtimaan, olisiko painoon mennyt vahingossa artikkelin varhaisempi versio. Tämä voisi selittää esityksen rönsyilyn, tekstiin jääneet kielivirheet ja puutteelliset viitetiedot. Artikkeli on myös teoksen pisimpiä. Karsimalla sivumäärästä puolet pois, tästä olisi saattanut saada hyvinkin ansiokkaan artikkelin.

Pauli Kettunen tarkastelee omassa artikkelissaan työnjohtajakoulutuksen vaiheita Suomessa. Esityksen kerronnallinen jännite rakentuu Aksel Rafael Kurjen (1880-1950) varaan. Todellinen päähenkilö on kuitenkin tieteellinen työnjohto ja siihen liittyvä koulutus, jonka kehitystä Kettunen kuvaa alkaen Kurjen edustamasta psykoteknisestä lä- hestymistavasta ja päätyen työn rationalisointiin, tapaturmien torjuntaan ja me-hengen luontiin.

Artikkelin perusteella työntekijät oli tapana nähdä massana, joka työnjohtajan oli saatava toimimaan yhtiön tavoitteiden suuntaisesti. Samalla pyrittiin häivyttämään eri yhteisötyyppien eroavuudet: työpaikalla oltiin kuin yhtä perhettä. Päätöksentekoon henkilöstön ei tarvinnut osallistua eikä työelämän demokratisoitumista toivottu tai haluttu. Vilho Aukusti Niininen (1896-1980) oli poikkeus, joka tässä tapauksessa vahvistaa säännön. Osallistamisen sijaan työnjohdon oli keskityttävä vahvistamaan työpaikan "me-henkeä". Vaikka Kettunen ei asiaa varsinaisesti käsittelekään, artikkelista käy hyvin ilmi, kuinka vähän työnjohto-opeilla on ollut tekemistä kasvatuksen kanssa. Työnjohdon päämäärä ei ole henkilökunnan voimauttaminen vaan työvoiman hallinta. Kuulostaapa tutulta.

\section{AIKUISKASVATUKSEN NÄKÖALAT}

Teoksen kolmas pääjakso tarkastelee otsikkonsa mukaisesti aikuiskoulutuksen näköaloja. Jukka Tuomistolla aiheena on suunnittelukeskeinen aikuiskasvatuspolitiikka ja keskushenkilöinä yliopistomaailman puolelta Aulis Alanen (1929-1998) ja ammattiliiton edustajana koulutussihteeri Veli Lehtinen (s. 1937). Molemmat

\section{ILMAN P $\ddot{A T E V A ̈ ̈}$}

TIETOA IHMISTEN

OLI VAIKEA

HAHMOTTAA,

MITEN HE

VOISIVAT OLOJAAN

\section{KOHENTAA.}

olivat 1970-luvulla vahvasti mukana komiteatyössä, minkä tuloksena aikuiskasvatus nivellettiin osaksi valtakunnallista koulutuspolitiikkaa samalla kun aikuiskasvatuksen toimiala laajeni koskemaan vapaan sivistystyön lisäksi ammattikoulutusta.

Komiteatyön konkreettisina saavutuksina Tuomisto mainitsee jatkuvan koulutuksen periaatteen ottamisen koulutuspoliittisen suunnittelun lähtökohdaksi vuonna 1978 ja järjestöjen sivistystyön tueksi tarkoitetun opintokeskuslain hyväksymisen samana vuonna. Komitean työtä jatkoi aikuiskoulutuksen kehittämisorganisaatio (1979-1985) ja sittemmin myös Aikuiskoulutusneuvosto (1984-2009). Kahden avainhenkilönsä avulla Tuomisto onnistuu rakentamaan monipuolisen kuvan ajanjaksosta, jolloin aikuiskasvatuksen kenttää laajennettiin vapaasta sivistystyöstä työelämän tarpeiden palvelemiseen, samalla kun aikuiskoulutus nivel- 
lettiin osaksi kansallista koulutuspolitiikkaa.

\section{Koulutuspolitiikan murros}

Kirjan viimeisessä artikkelissa Heikki Silvennoinen luo katsauksen aikuiskasvatuksen vaiheisiin 1980-luvulta nykypäivään saakka. Artikkelissa vaikuttajiksi nousevat kollektiiviset toimijat, kuten korkein virkamieskunta ja poliittiset päättäjät sekä näille vaikutteita antaneet OECD ja Euroopan unioni. Tuomiston tapaan Silvennoinen kuvaa murrosta, jolloin koulutuspolitiikan johtavaksi aatteeksi nostettiin markkina-ajattelu, joka asteittain syrjäytti aiemmin vallalla olleen mahdollisuuksien tasaarvon periaatteen. Jos koulutus oli aiemmin palvellut kansanvallan lujittamista, nyt painopiste siirtyi talouselämän tarpeiden tyydyttämiseen.

Aikuiskasvatus muuttui yhä enemmän ammatillista osaamista lisääväksi aikuiskoulutukseksi ja jatkuvan koulutuksen idea elinikäiseksi oppimiseksi. Tämän kehityskaaren Silvennoinen kuvaa hienosti. Vähemmälle huomiolle jää, että samaan aikaan se, mitä aiemmin kutsuttiin vapaaksi sivistystyöksi, surkastui jonkinmoiseksi virkistystoiminnaksi. Sen avulla maksukykyiset harrastajat voivat purkaa palkkatyön paineita tai täyttää eläkevuosien tyhjyyttä - kun kaiken elämän täyttävä työ ei ole enää rytmittämässä arjen rutiineja.

\section{HAJAINEN}

\section{ARTIKKELIKOKOELMA}

Kantasen ja Nestin toimittama teos on osa Suomalaisen aikuiskasvatuksen kentät ja kerrostumat (SAKKE) -kirjahanketta, jonka tarkoitus on valottaa alan moninaisia käytäntöjä ja niiden taustoja. Hankkeen turvin on työstetty neljä artikkelikokoelmaa, joista kolme on saatu jo valmiiksi. Nyt käsillä olevan teoksen lisäksi on julkaistu Aikuisten kasvu ja aktivointi (toim. Anja Heikkinen \& Eeva Kallio) ja Aikuiskasvatus ja demokratian haaste (toim. Risto Rinne \& Arto Jauhiainen). Toimijoita ja vaikuttajia esittelevällä artikkelikokoelmalla on niin teemojensa kuin kirjoittajienkin osalta paljon yhteistä viimeksi mainitun kanssa.

Teoksen rakenteesta ja arvatenkin myös syntytavasta johtuen kuva jää hajanaiseksi ja osin jopa sattumanvaraiseksi. Esimerkiksi Talousseuran ohella tarkasteluun olisi yhtä hyvin voinut ottaa Turun Soitannollisen Seuran. Vastaavasti Anders Chydeniuksen rinnalla olisi voitu esitellä Anders Litzeliuksen, H.G. Porthanin tai vaikkapa Jacob Tengströmin näkemyksiä. Ja olisiko Snellmanin rinnalle pitänyt ottaa Agathon Meurman tai Yrjö Koskinen? Miksi Kansanvalistusseura saa esittelynsä mutta ei nelisenkymmentä vuotta aikaisemmin perustettu Suomalaisen Kirjallisuuden Seura? Entä sanoma- ja aikakaus- lehdistö, eikö myös näillä ollut aikuiskasvatuksellista merkitystä? Ja olisiko myös Yleisradio pitänyt jotenkin huomioida?

On selvää, että valintoja täytyy tehdä. Lukijana jäin kuitenkin kaipaamaan johdantotekstejä, joissa artikkeleissa esille nostetut toimijat ja instituutiot olisi nivottu osaksi laajempaa kulttuurihistoriallista kokonaisuutta. Nyt lukija saattaa näet erehtyä luulemaan, että tässä se aikuiskasvatuksen kehityshistoria sitten on.

Jotta teoksesta saisi irti kaiken sen, mitä siihen on ladattu, täytyy jo entuudestaan tuntea varsin hyvin suomalaista sivistystyön historiaa. Ratkaisua voi puolustella toteamalla, että semmoistahan se historia on, mosaiikkimaista. Vaan kun sitä se ei nimenomaan ole. Kerrottu historia ja varsinkin kirjamuotoon saatettu historia on aina ehyt kertomus, jolla on selkeä juoni. Nyt tarkasteltavassa teoksessa juoni jää aukkoiseksi. Tämä on harmillista, sillä itse artikkelit ovat poikkeuksellisen antoisia. Yksittäisten tekstiensä ansiosta teos soveltuukin erinomaisesti opetuskäyttöön, tosin enemmän artikkelikokoelmana kuin esityksen kattavuuteen pyrkivänä historiana.

\section{SELKOKIELEN HAASTE}

Teoksen kieliasu on pääosin moitteeton. Joihinkin teksteihin on jäänyt liikaa lyöntivirheitä, jotka olisi aihepiiriä tunteva oikolukija hel- 
posti korjannut. Myös esitystapaan liittyviä pikkuvirheitä löytyi riittämiin. Niinpä vaikka käytössä oli loppuviitteet, paikoin oli vielä jäljellä tekstinsisäisiä viittauksia.

Tekstiin sijoitettujen viitenumeroiden sijainti vaihteli ollen välillä yläindeksi ja välillä taas normaalifontti. Teoksen lopussa oli kaikille artikkeleille yhteinen kirjallisuusluettelo, mutta joissakin artikkeleissa kirjallisuusluettelo oli sijoitettu artikkelin yhteyteen. Harmillisempia ovat kuitenkin viitteiden puutteet. Loppuviitteitä puuttui ja osaa viitteissä mainituista lähteistä ei löytynyt mistään kirjallisuusluettelosta.

En ota näitä puutteita esiin siksi, että ne olisivat nimenomaan tässä teoksessa poikkeuksellisen yleisiä, vaan siksi, että aikamme tiedejulkaisuissa viimeistelemättömyys on enemmän sääntö kuin poikkeus. Olen itse ollut mukana toimittamassa artikkelikokoelmia ja tiedän, ettei virheistä voi syyttää sen enempää kirjoittajia kuin toimittajiakaan. Molemmat näet tulevat nopeasti tekstille sokeiksi. Siksi tarvitaan erikseen nimetty henkilö, joka kielenhuollollisten seikkojen ohella pystyy arvioimaan esityksen ymmärrettävyyttä ja johdonmukaisuutta. Tämä voisi edistää myös tieteellistä tiedonmuodostusta, sillä ainakin oman kokemukseni perusteella selkiytymättömiä ajatuksia on mahdotonta esittää selkokielisesti.
Risto Ikonen

$K T$, yliopistonlehtori

Kasvatustieteen ja

aikuiskasvatustieteen oppiaine

Itä-Suomen yliopisto 